\title{
DESIGN OF MULTI STOREY BUILDING RESTING ON SINGLE COLUMN
}

\author{
Madireddy Satyanarayana \\ Assistant Proffesor, Department of Civil Engineering, Lakireddy Balireddy College of Engineering \\ satyalbrce.ac.in@gmail.com
}

\begin{abstract}
The aim of the project is to analyze and design of multi-storey building resting on the single column by using different code provisions. A lay out plan of the proposed building is drawn by using AUTO CADD 2010.The structure consist of ground floor plus five floors, each floor having the one house. Staircase must be provides separately. The planning is done as per Indian standard code provisions. The building frames are analyzed using the various text books. Using this so many standard books analysis of bending moment, shear force, deflection, end moments and foundation reactions are calculated. Detailed structural drawings for critical and typical R.C.C. members are also drawn. Co-ordinates for all structural members are tabulated for ready reference.
\end{abstract}

Keywords: Multi Story Building, Single Column, Staircase.

\section{INTRODUCTION}

The purpose for taking in this project is to design a whole building rest on single column ${ }^{[1,2,3,5,6,7,9]}$. And how the different components are designed are given below in detailed.

- Design of the Foundation:

The type of foundation suitable for this multi- storey building is adopted based on the $\mathrm{SBC}^{[20,21]}$ value assumed. And it is designed by using standards of Indian codes and other ${ }^{[17,18,22,21]}$

- Design of the Column ${ }^{[8]}$.

One of the important task in this is design of Column because only mono column is assumed. The Column is designed by taking required dimensions according to ${ }^{[7,9,10,23,25]}$.

- Design of Beam:

The desired specifications of the beams are assumed according to Code Provisions ${ }^{[3,6,7]}$. And the checks are made according to that.

- Design of the Slab:

The required slab is assumed and it is designed with required specifications ${ }^{[15,16,18,19] \text {. }}$

The walls are construct in English bond .The specifications ${ }^{[}$ are lintel for various works. The limit state of design is adopted for designing all the RCC members.

There no existing structure practically but the design is comparing between various papers as references.

\section{METHODOLOGY}

The method we are design the entire structure is limit state method $^{[3]}$

\section{LIMITE STATE OF DESIGN:}

Limit state method of design in a factor improvement of ultimate load design.In the limit state method, a structure is designed to withstand all loads likely to act on in the duration of its life span also to satisfy the serviceability requirements likedeflection, limitation and crack width.

Table-1 Code book provisions

\begin{tabular}{|c|c|c|c|}
\hline $\begin{array}{l}\text { S. } \\
\text { no }\end{array}$ & $\begin{array}{l}\text { Type of the } \\
\text { structural } \\
\text { member }\end{array}$ & $\begin{array}{l}\text { Specifications of } \\
\text { member }\end{array}$ & $\begin{array}{l}\text { Design } \\
\text { provisions } \\
\text { used } \\
\end{array}$ \\
\hline 1. & $\begin{array}{l}\text { Foundation } \\
\text { (Isolated square } \\
\text { footing) }\end{array}$ & $9 \mathrm{mx} 12 \mathrm{~m}$ & $\begin{array}{l}\text { IS:456- } \\
2000\end{array}$ \\
\hline 2. & $\begin{array}{l}\text { Column } \\
\text { (SHORT, } \\
\text { COMPRESSION } \\
\text { MEMBER) }\end{array}$ & $2 \mathrm{~m} \times 2 \mathrm{~m}$ & $\begin{array}{l}\text { IS:456- } \\
2000\end{array}$ \\
\hline 3. & $\begin{array}{l}\text { Beam(Fixed } \\
\text { beams) }\end{array}$ & $450 \mathrm{~mm} \times 675 \mathrm{~mm}$ & $\begin{array}{l}\text { IS:456- } \\
2000\end{array}$ \\
\hline 4. & $\begin{array}{l}\text { Slab(Two way } \\
\text { slab) }\end{array}$ & Thickness $=150 \mathrm{~mm}$ & $\begin{array}{l}\text { IS:456- } \\
2000\end{array}$ \\
\hline 5. & $\begin{array}{l}\text { Stair } \\
\text { case(straight } \\
\text { flight stair case) }\end{array}$ & $\begin{array}{l}\text { Tread }(\mathrm{T})= \\
250 \mathrm{~mm} \\
\operatorname{Riser}(\mathrm{R})=150 \mathrm{~mm}\end{array}$ & $\begin{array}{l}\text { IS: 456- } \\
1978\end{array}$ \\
\hline
\end{tabular}

Hence thus using the above codes the method which is required for the design of this Multi-Storey Building is adopted.

\section{GEOMETRY OF THE STRUTURE}

A multi-storey building resting on the single column ${ }^{[1,2]}$ is planned for the analysis and design its plans is shown in figure 1(a) and 1(b) 


\section{BUILDING ORIENTATION:}

The building is oriented in such a way that it is going to serve with lights and air circulation ${ }^{[12]}$ with easy access to all amenities. Basic facilities in residential building are given as per the $\mathrm{NBC}^{[25]}$ Recommendations.

Each floor consists of the individual of the house that consists of two bed rooms, kitchen, hall, separate toilets, dining hall and pooja room.

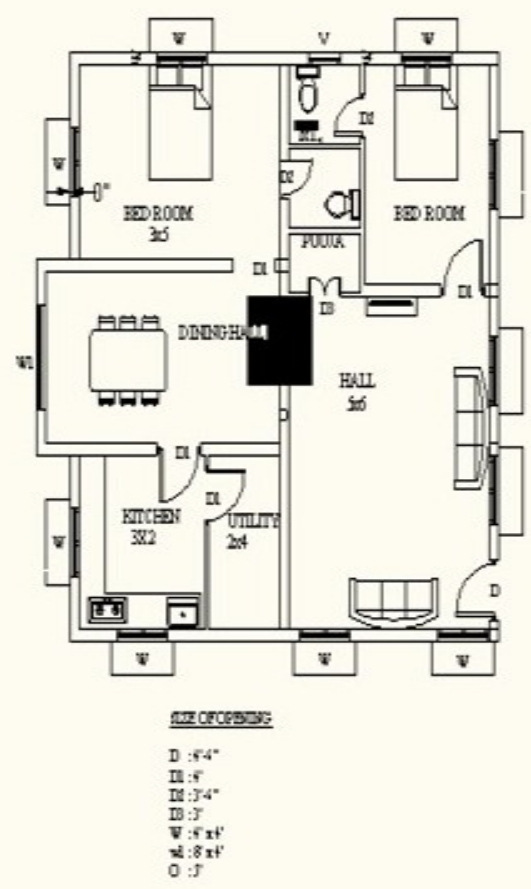

Fig.1 (a) Plan of the Building

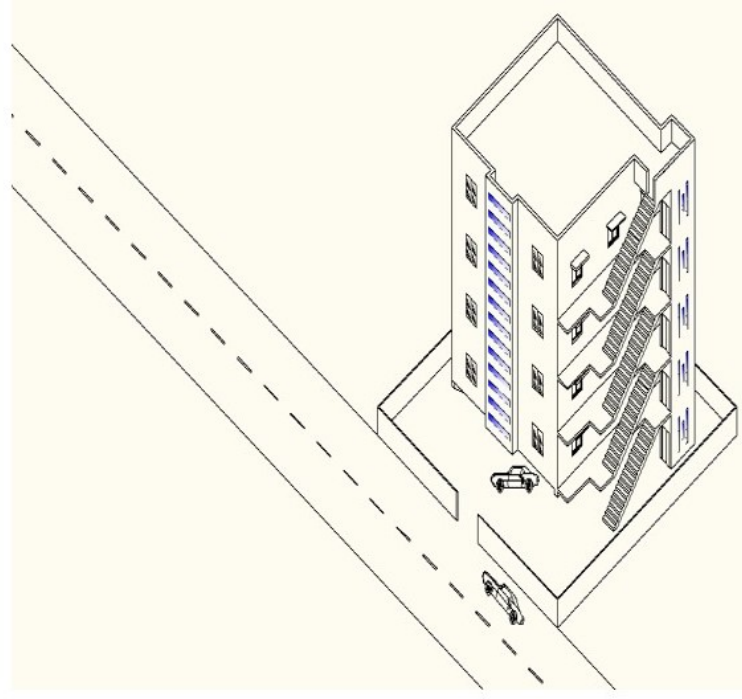

Fig. 1 (b) Detailed view of Building Elevation

\section{PLANNING DETAILS ${ }^{[22]}$}

O Bed room $1=3 \mathrm{mx} 5 \mathrm{~m}$

○ Bed room $2=3 \mathrm{~m} \times 5 \mathrm{~m}$

- Dining hall $=3 \mathrm{mx} 3 \mathrm{~m}$

- Kitchen $=3 \mathrm{~m} \times 4 \mathrm{~m}$

○ Hall $=5 \mathrm{mx} 6 \mathrm{~m}$

- Total area $=400 \mathrm{~m}^{2}$

- Built up area $=117 \mathrm{~m}^{2}$ toilet $1=2 \mathrm{mx} 1.5 \mathrm{~m}$

toilet $2=2 \mathrm{mx} 1.5 \mathrm{~m}$

pooja room $=1 \mathrm{mx} 1 \mathrm{~m}$ utilities $=2 \mathrm{~m} \times 4 \mathrm{~m}$

Table-2 Design of the members in detailed

\begin{tabular}{|c|c|c|c|}
\hline S.NO & $\begin{array}{l}\text { NAME OF } \\
\text { THE } \\
\text { MEMBER }\end{array}$ & DETAILS OF DESIGN & REMARKS \\
\hline 1. & Footing & $\begin{array}{l}\text { DESIGN OF MAT FOUNDATION: } \\
\text { Size of the building }=9 \times 12 \mathrm{~m} \\
\text { Service load transmitted by each column }=7250 \mathrm{KN} \\
\text { Size of the column }=2 \mathrm{mx} 2 \mathrm{~m} \\
\text { Safe bearing capacity of the soil }=120 \mathrm{KN} / \mathrm{m}^{2} \\
\text { M20, } \mathrm{f}_{\mathrm{ck}}=20 \mathrm{KN} / \mathrm{m}^{2} \text { and } \mathrm{f}_{\mathrm{y}} 415 \mathrm{HYSD} \text { bars. } \\
\text { And then continuous slab over Raft slab is designed. }\end{array}$ & $\begin{array}{l}\text { According to the } \\
\text { code provisions } \\
\text { check is ok. }\end{array}$ \\
\hline 2. & Column & $\begin{array}{l}\text { COLUMN DESIGN: } \\
\text { Design of Column is done as per IS: } 456-2000 \\
\text { Section Property: } 2000 \times 2000 \text {, Storey height }=16.500 \mathrm{~m} \\
\text { Rectangular section: } \\
\text { Width= } 2000 \mathrm{~mm} \text {, Depth=2000 mm, Cover }=40 \mathrm{~mm} \\
\text { Member Detailed IS456 Main Reinforcement, } \\
\text { Critical Combination : C4 } \\
\text { And all other manual design is done by used standard code. }\end{array}$ & $\begin{array}{l}\text { All the checks are } \\
\text { ok hence it is safe. }\end{array}$ \\
\hline 3. & Beam & $\begin{array}{l}\text { BEAM CALCULATIONS: } \\
\text { Assume the thickness of the beam is } 450 \times 600 \\
\text { Imposed load }=3 \mathrm{KN} / \mathrm{m} 2 \\
\text { Live load is for all rooms\& Kitchens, } \\
\text { toilet and Bath rooms }=2 \mathrm{KN} / \mathrm{m} 2 \text { and } \\
\text { self-weight is calculated as } 3 \mathrm{KN} / \mathrm{m} 2\end{array}$ & $\begin{array}{l}\text { All the checks are } \\
\text { ok hence it is safe }\end{array}$ \\
\hline
\end{tabular}




\begin{tabular}{|c|c|c|c|}
\hline & & $\begin{array}{l}\text { (According to IS } 456 \text { part } 2 \text { ) } \\
\text { Provide } 10 \mathrm{~mm} \text { dia } 240 \mathrm{~mm} \text { centre for long span direction } \\
\text { And the other manual required design is done by using codes } \\
\text { and other reference books for all other rooms in the } \\
\text { multi -storey building }\end{array}$ & \\
\hline 4. & Roof slab & $\begin{array}{l}\text { DESIGN OF ROOF SLAB }[14,17] \\
1_{\mathrm{y}}=5 \mathrm{~m}, \mathrm{l}_{\mathrm{x}}=3 \mathrm{~m}, \mathrm{f}_{\mathrm{ck}}=20 \mathrm{~N} / \mathrm{mm}^{2} \text { and } \mathrm{f}_{\mathrm{y}}=415 \mathrm{~N} / \mathrm{mm}^{2} \\
\text { Where } 1_{\mathrm{y}} / 1_{\mathrm{x}} \text { ratio is }<2 \\
\text { Design as a two way slab. } \\
\text { As the span is more than } 3.5 \mathrm{~m} \text { adopt Span } / \text { depth }=25 \\
(\text { Condition according the IS } 456) \\
\text { Depth }=\text { span } / 25=3.5 / 25=114.85 \mathrm{~m}, \text { Say }=120 \mathrm{~mm} \\
\text { Adopt effective depth }(\mathrm{d})=95 \mathrm{~mm} \text { and } \\
\text { Overall depth }(\mathrm{D})=120 \mathrm{~m} \\
\text { EFFECTIVE SPAN: } \\
\text { Effective span }=(\text { clear span }+ \text { effective depth) } \\
=3.00+0.095=3.095 \mathrm{~m} \\
\text { Loads are taken from codes and Ultimate load }=8.4 \mathrm{KN} / \mathrm{m}^{2} \text {. } \\
\text { And the shear force and ultimate bending moments are } \\
\text { designed. } \\
\text { Hence the effective depth selected is sufficient to resist the } \\
\text { design of ultimate moment. } \\
\text { Adopt } 10 \mathrm{~mm} \text { dia } @ 300 \mathrm{~mm} \text { in shorter span direction. }\end{array}$ & $\begin{array}{l}\text { All the checks are } \\
\text { ok hence it is safe }\end{array}$ \\
\hline 5. & Stair case & $\begin{array}{l}\text { STAIR CASE DESIGN } \\
\text { Type of the stair case is straight flight stair case } \\
\text { No. of steps in straight flight is } 12 \\
\text { Tread }(T)=250 \mathrm{~mm} \text {, Rise }(\mathrm{R})=150 \mathrm{~mm} \\
\text { Width of the landing beams }=400 \mathrm{~mm} \text { and } \\
\text { Materials M } 20 \text { and } \mathrm{f}_{\mathrm{y}} 415 \\
\text { EFFECTIVE SPAN : } \\
\text { Effective span } \mathrm{l}=(12 \times 250)+400=3400 \mathrm{~mm} \\
\text { Thickness of the waist slab is }(\mathrm{span} / 20)=3400 / 20=170 \mathrm{~mm} \text {, } \\
\text { Say }=200 \mathrm{~mm} \\
\text { And all necessary checks are done by using code provisions. } \\
\text { Provide } 12 \mathrm{~mm} \text { of diameter and Spacing }=160 \mathrm{~mm} \\
\text { Distribution of the reinforcement }=0.12 \% \text { bD } \\
\text { Provide } 8 \mathrm{~mm} \text { 0f dia of bars at c/c. }\end{array}$ & $\begin{array}{l}\text { All the checks are } \\
\text { ok hence it is safe. }\end{array}$ \\
\hline
\end{tabular}

\section{RESULTS}

1. In this project a multi-storey building resting on single column designed by using of STAAD PRO 2007.

2. Using of this software analysis of bending moment, shear force, deflections, end moments and foundation reactions are calculated.

3. Using this calculated Bending moment, shear force, and reactions the beams, columns and footingare designed.

4. By using the AUTO CAD ${ }^{[1]}$ we can design the footing.

5. Detailed drawings of all R.C.C. members such as slabs, beams, columns, and footings are also shown.

\section{CONCLUSION}

1. We conclude our project with full satisfaction that we are designed the

2. Multi-storey building resting on single column by using of the AUTO CAD ${ }^{[1]}$.

3. The limit state method of design is adopted. We had done the design aspects of the structure manually and software. ${ }^{[1]}$
4. In our project we also used the code provision of the SP 16 and SP 34 (the design aids for concrete and detailing)

5. Finally we learn detailing of various structural members by using SP 34 design aids.

6. The knowledge gained from this project will help us to take up similar projects with courage and confidence in future course of actions.

\section{REFERENCES}

[1]AUTO CADD 2010.

[2] REINFORCED CONCRETE DESIGN BY KRISNARAJU AND R.N.PRANESH AS PER IS 4562000

[3] VARGEESE .P.C. LIMIT STATE DESIGN OF REINFORCEMENT CONCRETE

[4] SP 16 - DESIGN AIDS FOR REINFORCED CONCRETE

[5] SP 34- AIDS FOR DETAILING OF R.C MEMBERS.

[6] IS 456:2000 Plain and reinforced concrete -code of practice, New Delhi. 
[7] IS 875:1987 (PART 1) code of practice for design loads (other than earth quake loads) for building and structures, New Delhi (India), Bureau of Indian standard, 1987.

[8] Analysis and design of an office building with mono column byE K Mohanraj*, Kongu Engineering College, IndiaS Nisar Ahmad, Kongu Engineering College, India

A Gowri Sankar, Kongu Engineering College, India27th Conference on OUR WORLD IN CONCRETE \& STRUCTURES:29 - 30 August 2002,Singapore

[9] IS 875:1987 (PART 2) code of practice for design loads (other than earth quake loads) for building and structures, new Delhi(India), Bureau of Indian standard, 1987.

[10] IS $875: 1987$ (PART 3) code of practice for design loads

(other than earth quake loads) for building and structures, new Delhi(India),Bureau of Indian standard,1987.

[11] INTERNATIONAL JOURNAL OF ENGINEERING SCIENCES \& RESEARCHTECHNOLOGYDesign of Multistoried R.C.C. Buildings with and without Shear WallsM. S. Aainawala Dr. P. S. Pajgade Size of members like column can be reducedeconomically in case of structure with shearwall as compared to the same structurewithout shear wall.

[12] YUN, hyun-do, CHOI, Chang-sik and LEE, li-hyung, "Earthquake performance of highstrengthconcrete structural walls withboundary elements" 13th World Conferenceon Earthquake Engineering, Vancouver,B.C., Canada August 1-6, 2004.

[13] Anshuman. S, Dipendu Bhunia, BhavinRamjiyani, "Solution of Shear Wall Locationin Multi-Storey Building" internationaljournal of civil and structural engineering,volume 2, no 2, 2011.

[14] Varsha R. Harne, "Comparative study ofstrength of RC Shear wall at differentlocation on multistoried residential building" International Journal of CivilEngineering Research. ISSN 2278-3652Volume 5, Number 4 (2014), pp. $391-400$

[15] Ashish S. Agrawal and S.D. Charkha, "Studyof Optimizing Configuration of Multi-StoreyBuilding Subjected to Lateral Loads

[16] A text book of Limit State of Design by B.C.Punmia Ashok k Jain Arun Kumar Jain, Arun Kr. Jain

[17]Foundation Design And Analysis With A Practical Approach By Sharat Chandra Gupta.

[18]Cook, N.J., The designer's guide to wind loading of building structures - Part 1". Butterworths, London, 1985.

[19]Venkateswarlu, B., Arunachalam, S., Shanmugasundram, J., and Annamalai, G., "Variation of Wind Speed with Terrain Roughness and Height", Journal of Institution of Engineers, Vol. 69, CI.64, January, 1989.

[20]IS: 11384, Code of practice for composite construction in structural steel and concrete, Bureau of Indian Standards, New Delhi, 1985.

[21] Christopher J. Earls (2000), “Geometricfactors influencing structural ductility incompact I shaped beams", Journal ofStructural Engineering, Vol 126, No. 7,pp. 780789.

[22] A text book of Soil Mechanics and Geotechnical Engineering by D.L. Shah,A.V. Shroff.
[23] Journal of the National Institute of Building Sciences (JNIBS) in June 2013.

[24] National Council of Governments on Building Codes and Standards (NCGBCS). 